SUBJECT AREAS:

GEOCHEMISTRY

MATERIALS CHEMISTRY

INORGANIC CHEMISTRY

Received

12 November 2013

Accepted

30 January 2014

Published

26 February 2014

Correspondence and requests for materials should be addressed to Y.Y. (yokomori@nda. ac.jp)

\section{Final storage of radioactive cesium by pollucite hydrothermal synthesis}

\author{
Yoshinobu Yokomori' ', Kazuhito Asazuki', Natsumi Kamiya', Yudai Yano', Koki Akamatsu', \\ Tetsuya Toda' ', Atsushi Aruga' ', Yoshiaki Kaneo², Seiko Matsuoka², Koji Nishi' \& Satoshi Matsumoto³
}

\begin{abstract}
'Department of Applied Chemistry, National Defense Academy, Hashirimizu, Yokosuka 239, Japan, ${ }^{2}$ Zero Sum Earth Co. Ltd., 6-8-081 Ichiba-cho, Chuo-ku, Chiba 260-0855, Japan, ${ }^{3}$ Emeritus Professor, Graduate School of Agricultural and Life Sciences, The University of Tokyo, Bunkyo-ku, Tokyo, Japan.
\end{abstract}

The Fukushima nuclear accident has highlighted the importance of finding a better final storage method for radioactive cesium species. Cs is highly soluble in water, and can easily exchange with other alkali ions in zeolites or clays to form stable complexes. However, $\mathrm{Cs}^{+}$is released from $\mathrm{Cs}^{+}$complexes into water when surrounded by an excess of water. Pollucite may be the best final storage option for $\mathrm{Cs}^{+}$, but its typical synthesis requires heating to about $1200^{\circ} \mathrm{C}$ in air. Here, we show that the hydrothermal synthesis of pollucite can be completed at $300^{\circ} \mathrm{C}$ in three hours from any zeolite or clay. Furthermore, our procedure does not require ion exchange before synthesis. Radioactive Cs is usually found in complexes with clays. At that time, this method only requires calcium hydroxide, water, and three hours of hydrothermal synthesis, so the process is both inexpensive and practical for large-scale application. Pollucite is an analog of analcime zeolite, and contains a channel system $2.8 \AA$ in diameter, which is formed by 6-oxygen rings. As the diameter of $\mathrm{Cs}^{+}$is $3.34 \mathrm{~A}^{\circ}$ and each $\mathrm{Cs}^{+}$exists independently within a separate portion of the channel, $\mathrm{Cs}^{+}$cannot exit the pollucite framework without breaking it.

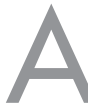

fter the Fukushima nuclear accident on March 11, 2011, there are still strong emissions of radioactive cesium near the nuclear power plant. The removal and final storage of this cesium is an urgent issue, especially since no good final storage method has yet been discovered. Generally speaking, radioactive cesium is very soluble in water, like other alkali metal elements, but it also binds strongly with clays ${ }^{1,2}$, so the resulting spread of radiation will cover a wide area and continue for a long time. Many studies have described the successful immobilization of cesium ${ }^{3}$, but all of the reported methods are suitable for high-level nuclear waste. Radioactive cesium was spread out over a very wide area around the Fukushima nuclear power plant, and most of it is now tightly bound to the clay in the soil. It is very difficult to release these radioactive cesium ions without breaking layer structure of the clay. This will greatly increase the total cost of cleanup. Our procedure will directly convert Cs-clay complex into pollucite.

Pollucite belongs to the analcime zeolite family $y^{4-7}$, and is one of the best final storage options for radioactive $\mathrm{Cs}^{8-10}$ because it has an appropriately sized channel and does not release the radioactive $\mathrm{Cs}^{+}$ions without complete destruction of the zeolite framework ${ }^{23}$. Figure 1 shows the channel system in pollucite and several $\mathrm{Cs}^{+}$ions. The distance between two $\mathrm{Cs}^{+}$ions in the channel is $5.92 \AA^{11,12}$. The channel is constructed from 6oxygen rings and has a diameter of $2.8 \AA^{13-15}$. The diameter of the $\mathrm{Cs}^{+}$ion is $3.34 \AA^{16}$, so that after the pollucite has formed, it cannot release the trapped $\mathrm{Cs}^{+}$ions without destroying the zeolite framework. Pollucite is a natural mineral ${ }^{17}$, and is also the principal source of elemental cesium ${ }^{18}$. This means that $\mathrm{Cs}^{+}$ions within natural pollucite are not released, even over a long period of time. Unfortunately, pollucite is normally synthesized at about $1200^{\circ} \mathrm{C}$ in air ${ }^{19-22}$, or hydrothermally from certain specific zeolites. For example, chabazite transforms into pollucite at $240^{\circ} \mathrm{C}$ in 6 days $\mathrm{s}^{23}$ and phillipsite changes into pollucite at $300^{\circ} \mathrm{C}$ in 13 hours ${ }^{24}$.

We show here a very promising storage method for radioactive Cs. The synthetic mixture had the following molar composition: $1 \mathrm{CLP}-10.5 \mathrm{AlCl}_{3}-32 \mathrm{Ca}(\mathrm{OH})_{2}-32 \mathrm{CsCl}-2300 \mathrm{H}_{2} \mathrm{O}$, where CLP represents clinoptilolite (Na, $\mathrm{K})_{6} \mathrm{Al}_{6} \mathrm{Si}_{72} \mathrm{O}_{196} \cdot \mathrm{nH}_{2} \mathrm{O}$, an abundant natural zeolite. Only stable Cs was used in the present experiments. Pollucite was synthesized at $300^{\circ} \mathrm{C}$ in 3 hours by hydrothermal synthesis, and the hydrothermal pressure was about 8.5 MPa. Pollucite was also synthesized in 3 hours from mordenite (MOR), which is another rich natural zeolite, and even from smectite clay (SMT) at $300^{\circ} \mathrm{C}$. All yields were close to $100 \%$. At $240^{\circ} \mathrm{C}$ and $3 \mathrm{MPa}$, pollucite can be completely synthesized in 12 days from MOR and in 6 days from CLP, and in a single day from SMT. X-ray fluorescence based elemental analysis of pollucite yielded the following results: $\mathrm{Si}: \mathrm{Al}: \mathrm{Cs}: \mathrm{Ca}=32: 15: 14.3: 1.0$ 


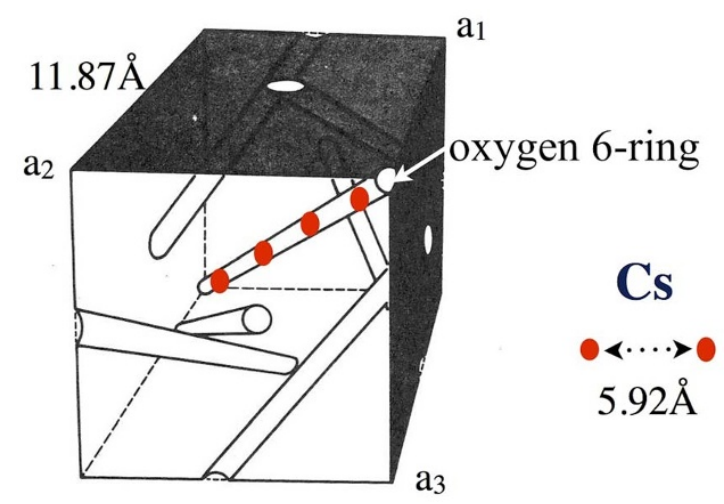

Figure 1 | Illustration of pollucite. Pollucite has the same framework and the same channel system as analcime, so that $\mathrm{Cs}^{+}$ions were added into the analcime framework illustrated by Breck ${ }^{28}$. The diameters of the 6-oxygen ring and the $\mathrm{Cs}^{+}$ion are $2.8 \AA$ and $3.34 \AA$, respectively.

(from MOR), $32: 20.2: 11.8: 0.2$ (from CLP), $32: 12.2: 10.8: 0$ (from SMT), and $32: 14.5: 11.4: 0$ (from natural pollucite). XRD data for pollucite formed from CLP are shown in Fig. 2, with pollucite patterns calculated from the reference ${ }^{13}$. The pattern is the same as the patterns shown on ICDD card number 00-029-0407, PDF2 files. The synthetic process is shown in Fig. 3, and a photograph of the synthesized pollucite is shown in Fig. 4.

It is generally recognized that pollucite is the best storage medium for radioactive Cs, but the synthetic method in air at $1200^{\circ} \mathrm{C}$ is very expensive and exhibits a problematic Cs volatilization at $1200^{\circ} \mathrm{C}$. Fortunately, the cost can be drastically reduced by employing a three-hour hydrothermal synthesis with $\mathrm{Ca}(\mathrm{OH})_{2}$ at $300^{\circ} \mathrm{C}$. This method is also very environmentally friendly, because no reagents

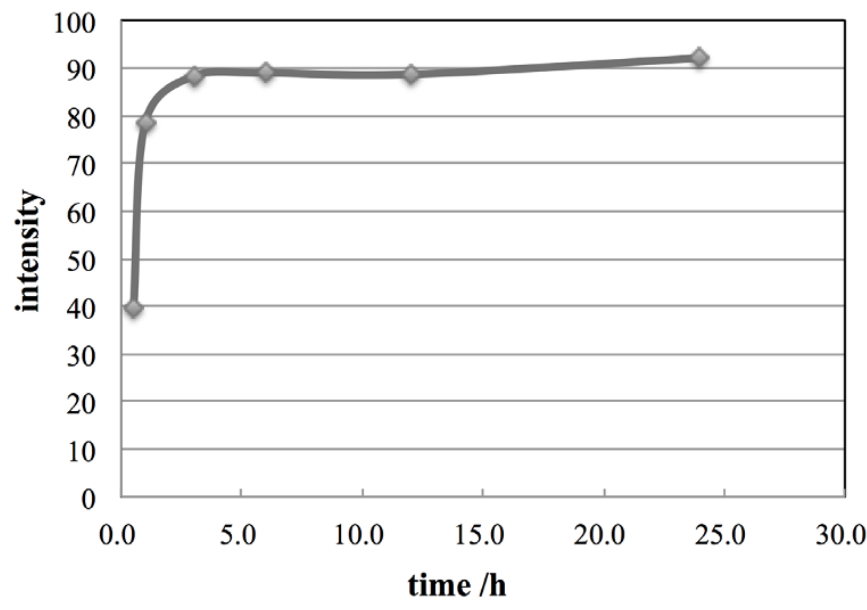

Figure 3 Crystallization curve for the formation of pollucite from clinoptilolite at $300^{\circ} \mathrm{C}$. X-ray intensity vs. synthetic time (hours).

other than $\mathrm{Ca}(\mathrm{OH})_{2}$ are used, and there is no significant Cs volatilization in the hydrothermal synthesis. Almost all other known storage methods involve ion-exchange substances, which all release absorbed radioactive Cs into the environment sooner or later ${ }^{1}$ without special treatment ${ }^{25}$ after adsorption. On the other hand, pollucite sequesters each Cs ion in a separate compartment, and the doorway to this compartment is smaller ( $2.8 \AA$ in diameter) than the Cs ion itself ( $3.34 \AA$ in diameter). Therefore, the Cs ion is not easily released from the pollucite framework, even if the framework becomes cracked. Only by breaking the framework completely apart can the Cs ion be released ${ }^{23,26}$. We focus on the final storage of radioactive cesium released into the environment. In this case, beta radiation

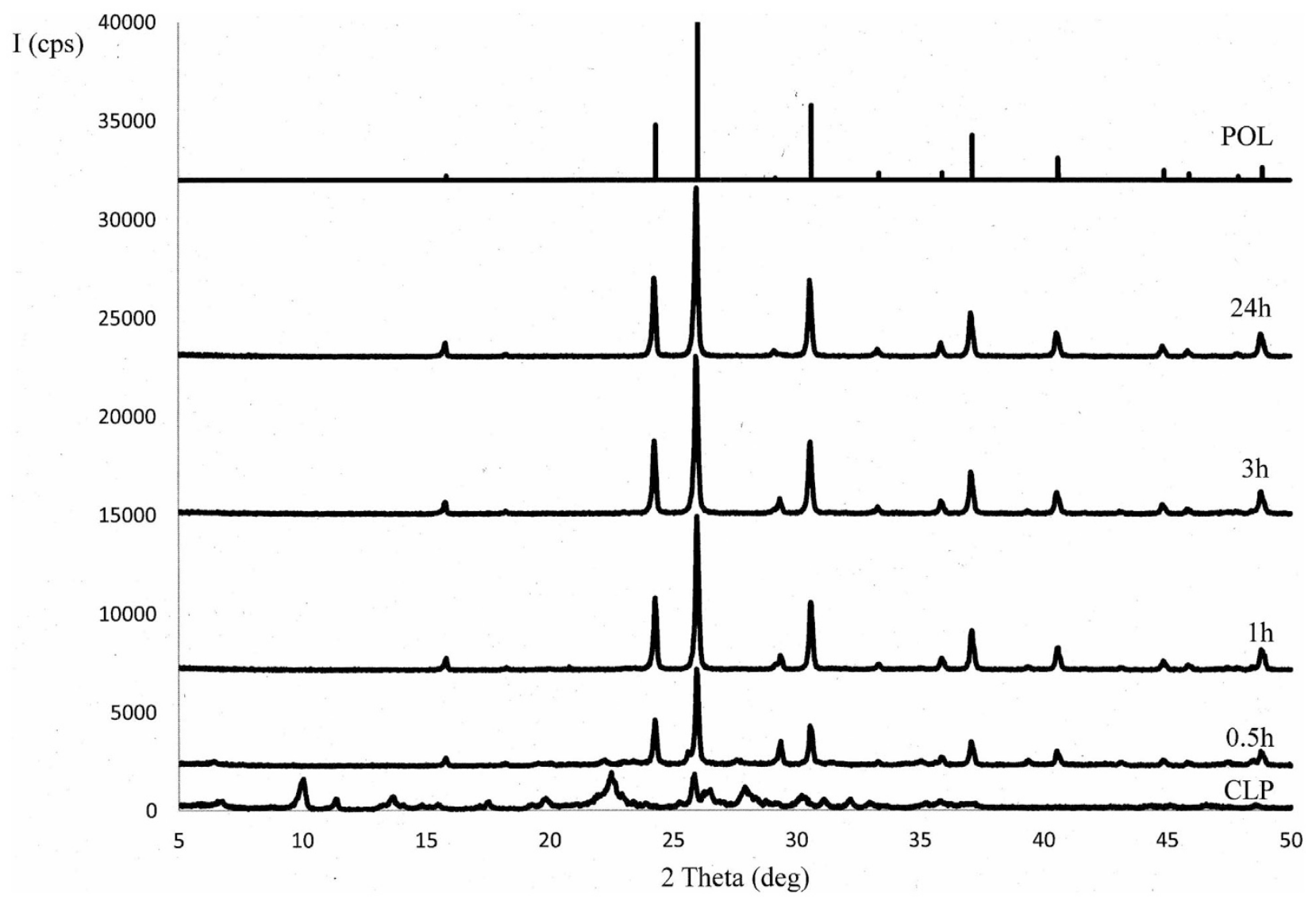

Figure $2 \mid$ XRD patterns of pollucite from clinoptilolite at $300^{\circ} \mathrm{C}$. 


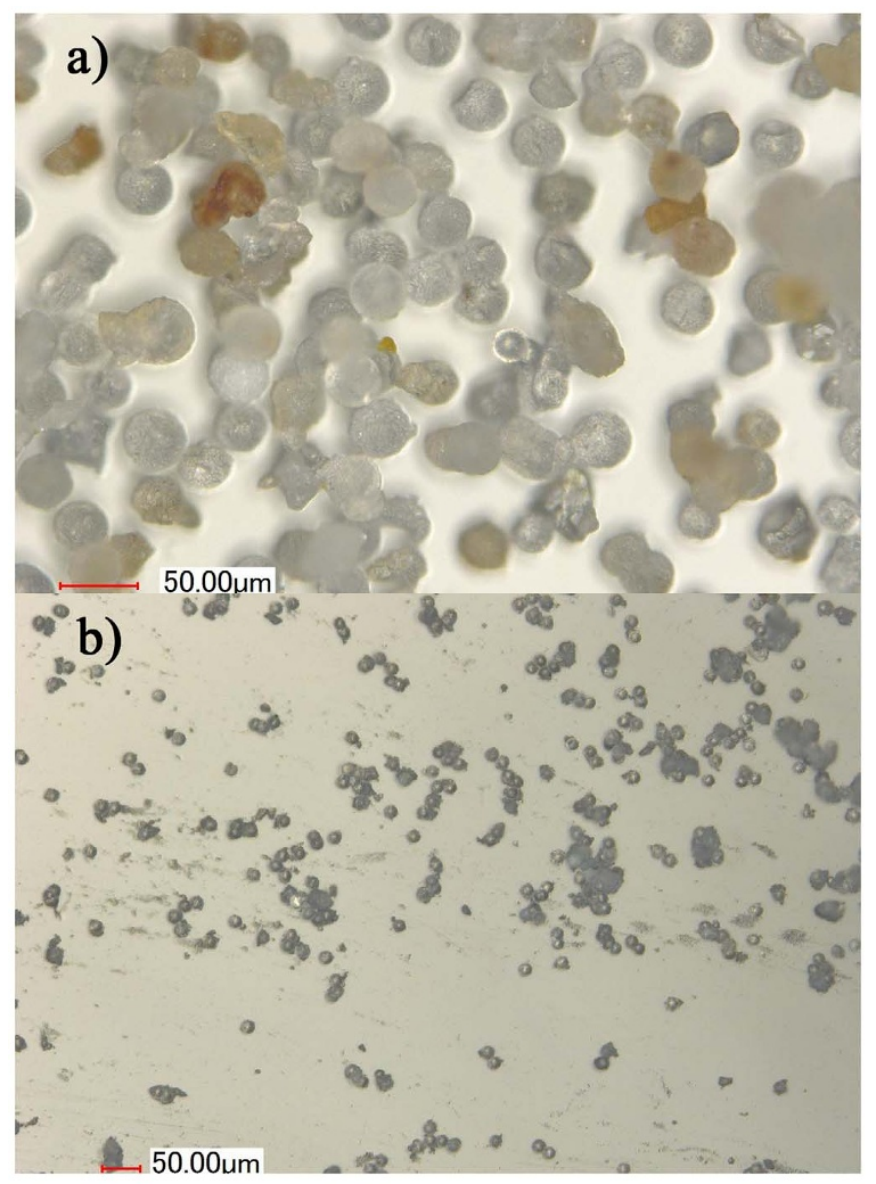

Figure $4 \mid$ Photos of synthetic pollucite at $240^{\circ} \mathrm{C}$. The samples were treated with $0.1 \mathrm{~N} \mathrm{HCl}$ for one hour to dissolve the $\mathrm{CaCO}_{3}$. (a) 12 days from mordenite, and (b) 6 days from clinoptilolite.

results in transmutation, which changes both the ionic radius and valence of the element undergoing decay. The radiation damage over 20 years has been researched, and the results indicate that the pollucite structure remains remarkably unaffected by this transmutation $^{27}$. Pollucite contains many Cs ions (more than $40 \mathrm{wt} \%$ ) in its framework, is quite heavy, with a specific gravity of $2.94^{18}$, and is insoluble in water. Therefore, synthetic radioactive pollucite should be sunk to the bottom of lakes and ponds rather than buried under the ground. This procedure is the safest, easiest, and least expensive option. Our method is to directly convert radioactive Cs in the soil into pollucite. The produced pollucite in the soil is very stable to water, heat, and transmutation for a long time, although the method does not reduce the volume of soil containing radioactive Cs. We believe that the produced pollucite is so fine (less than 10 micrometers in particle diameter), and capable of solidification in cement along with the soil. The resulting compact cement blocks should be sunk into a lake or the sea rather than buried in the ground. It is not always the best way to concentrate radioactive cesium from the soil. As the concentration of radioactive cesium increases, the risk of radiation damage will increase, and the efficiency of processing the contaminated soil will worsen.

\section{Methods}

The synthetic mixture had the following molar composition when using MOR or SMT instead of CLP: $1 \mathrm{MOR}-12 \mathrm{AlCl}_{3}-30 \mathrm{Ca}(\mathrm{OH})_{2}-40 \mathrm{CsCl}-2300 \mathrm{H}_{2} \mathrm{O}$ or $1 \mathrm{SMT}-$ $1.5 \mathrm{AlCl}_{3}-33 \mathrm{Ca}(\mathrm{OH})_{2}-33 \mathrm{CsCl}-2300 \mathrm{H}_{2} \mathrm{O}$, respectively. MOR represents mordenite $\left(\mathrm{Na}_{8} \mathrm{Al}_{8} \mathrm{Si}_{40} \mathrm{O}_{96} .24 \mathrm{H}_{2} \mathrm{O}\right)$ and $\mathrm{SMT}$ indicates smectite, a kind of clay with the following chemical composition: $\mathrm{SiO}_{2}(63.8 \mathrm{wt} \%), \mathrm{Al}_{2} \mathrm{O}_{3}(24.9 \mathrm{wt} \%), \mathrm{CaO}(0.6 \mathrm{wt} \%)$, $\mathrm{Na}_{2} \mathrm{O}(3.7 \mathrm{wt} \%)$, and $\mathrm{K}_{2} \mathrm{O}(0.1 \mathrm{wt} \%)$. The unit cell formula of pollucite is $\mathrm{Cs}_{16} \mathrm{Al}_{16} \mathrm{Si}_{32} \mathrm{O}_{96}$, and $\mathrm{AlCl}_{3}$ was added until the concentration ratio of [Al] to [Si] became $1 / 2$ in the synthetic mixture. $\mathrm{Ca}(\mathrm{OH})_{2}$ was also added until the ratio of $[\mathrm{OH}]$ to [Si] became 1 in the synthetic mixture. Hydrothermal syntheses were carried out at $240^{\circ} \mathrm{C}$ for $1,2,4,6,8,10,12,14$, and 16 days and at $300^{\circ} \mathrm{C}$ for $0.5,1,3,6,12$, and 24 hours.

1. Nakanishi, T. M. [Chapter 1. The overview of our research] Agricultural Implications of the Fukushima Nuclear Accident [Nakanishi, T. M. \& Tanoi, K. (eds.)] [1-10] (Springer, Tokyo, 2013).

2. Shiozawa, S. [Chapter 6. Vertical migration of radiocesium fallout in soil in Fukushima] Agriculture Implications of the Fukushima Nuclear Accident [Nakanishi, T. M. \& Tanoi, K. (eds.)] [49-60] (Springer, Tokyo, 2013).

3. Popa, K. \& Pavel, C. C. Radioactive wastewater purification using titanosilicate materials: State of the art and perspectives. Desalination 293, 78-86 (2012).

4. Yokomori, Y. \& Idaka, S. The crystal structure of analcime. Microporous Mesoporous Mater. 21, 365-370 (1998).

5. Taylor, W. H. The structure of analcime $\left(\mathrm{NaAlSi}_{2} \mathrm{O}_{6} \cdot \mathrm{H}_{2} \mathrm{O}\right)$. Z. Kristallogr. 74, 1-19 (1972).

6. Knowles, C. R., Rinaldi, F. F. \& Smith, J. V. Refinement of the crystal structure of analcime. Indian Mineral. 6, 127-140 (1965).

7. Ferraris, G., Jones, D. W. \& Yerkess, J. A neutron-diffraction study of the crystal structure of analcime, $\mathrm{NaAlSi}_{2} \mathrm{O}_{6} \cdot \mathrm{H}_{2} \mathrm{O}$. Z. Kristallogr. 135, 240-252 (1972).

8. Komarneni, S. \& Roy, R. Zeolites for fixation of cesium and strontium from radwastes by thermal and hydrothermal treatments. Nuclear and Chemical Waste Management 2, 259-264 (1981).

9. Gallagher, S. A. \& McCarthy, G. J. Preparation and X-ray characterization of pollucite $\left(\mathrm{CsAlSi}_{2} \mathrm{O}_{6}\right)$. J. Inorg. Nucl. Chem. 43, 1773-1777 (1981).

10. Park, S., Gies, H., Toby, B. H. \& Parise, J. B. Characterization of a new microporous lithozincosilicate with ANA Topology. Chem. Mater. 14, 3187-3190 (2002).

11. Kamiya, N., Nishi, K. \& Yokomori, Y. Crystal structure of pollucite. Z. Kristallogr. 223, 584-590 (2008).

12. Palmer, D. C., Dove, M. T., Ibberson, R. M. \& Powell, B. M. Structural behavior, crystal chemistry, and phase transitions in substituted leucite; high-resolution neutron powder diffraction studies. Amer. Mineral. 82, 16-29 (1997).

13. Beger, R. M. The crystal structure and chemical composition of pollucite. Z. Kristallogr. 129, S280-302 (1969)

14. Taylor, W. H. Note on the structure of analcite and pollucite. Z. Kristallogr. 99, 283-291 (1938).

15. Tayler, D. \& Henderson, C. M. B. The thermal expansion of the leucite group of minerals. Amer. Mineral. 53, 1476-1489 (1968).

16. Berger, L. I. [Ionic radii in crystals] CRC Handbook of Chemistry and Physics 90th Edition [Lide, D. R. (ed.)] [12-11] (CRC Press, 2009).

17. Nel, H. J. Pollucite from Karibib, Southwest Africa. Am. Mineral. 29, 443-452 (1944).

18. Newnham, R. E. Crystal structure and optical properties of pollucite. Am. Mineral. 52, 1515-1518 (1967)

19. Gallagher, S. A. \& McCarthy, G. J. High temperature stability of $\mathrm{CsSiO}_{4}$ and CsAlSi $\mathrm{O}_{6}$. Mat. Res. Bull. 17, 89-94 (1982).

20. Goto, Y., Matsuzawa, J. \& Matsuda, S. Removal of cesium and strontium by natural zeolites and the improved zeolites from aqueous solution and their fixation in the zeolites. Proceedings of the VII International Clay Conference 1981, Bologna and Pavia, Italy, Elsevier, 1982 (1981, September, 6-12).

21. Mimura, H. \& Kanno, T. Distribution and fixation on cesium and strontium in zeolite A and chabazite. J. Nucl. Sci. Technol. 22, 284-291 (1985).

22. Torres-Martinetz, L. M., Gard, J. A., Howie, R. A. \& West, A. R. Synthesis of $\mathrm{Cs}_{2} \mathrm{BeSi}_{5} \mathrm{O}_{12}$ with pollucite structure. J. Solid State Chem. 51, 100-103 (1984).

23. Barrer, R. M. Ion-exchange and ion-sieve process in crystalline zeolites. J. Chem. Soc. 1950, 2342-2350 (1950).

24. Komarneni, S. Phillipsite in Cs decontamination and immobilization. Clays Clay Miner. 33, 145-151 (1985).

25. Pavel, C. C., Walter, M., Poml, P., Bouexiere, D. \& Popa K. Contrasting immobilization behavior of $\mathrm{Cs}^{+}$and $\mathrm{Sr}^{2+}$ cations in a titanosilicate matrix. J. Mater. Chem. 21, 3831-3837 (2011)

26. Komarneni, S., McCarthy, G. J. \& Gallagher, S. A. Cation exchange behavior of synthetic cesium aluminosilicates. Inorg. Nucl. Chem. Letters 14, 173-177 (1978).

27. Fortner, J., Aase, S. \& Reed, D. Radiogenic transmutation effects in a crystalline alluminosilicate ceramic: a TEM study. Scientific Basis for Nuclear Waste Management XXV Materials Research Society 2001 Fall Meeting November 26-30, 2001 Boston, Massachusetts.

28. Breck, D. W. [Chapter 2. Structure of zeolites] Zeolite Molecular Sieves [Breck, D W. (ed.)] [29-185] (John Wiley \& Sons, Inc., 1974).

\section{Author contributions}

Y.Y. designed the project, performed experimental work, analyzed results, and wrote the manuscript. K.A., N.K., Y.Y., K.A. and T.T. performed experimental work. A.A. analyzed pollucite and Y.K., S.M. and K.N. designed the experimental work. S.M. oversaw and helped to write the manuscript. 


\section{Additional information}

Competing financial interests: The authors declare no competing financial interests.

(c) (1) (3) $\Theta$ This work is licensed under a Creative Commons Attribution-

How to cite this article: Yokomori, Y. et al. Final storage of radioactive cesium by pollucite (By No NonCommercial-NoDerivs 3.0 Unported license. To view a copy of this license, hydrothermal synthesis. Sci. Rep. 4, 4195; DOI:10.1038/srep04195 (2014). 